\title{
The safety of an autologous whole blood clot product applied to full thickness dermal wounds in a porcine model for up to 18 days
}

This article was published in the following Dove Press journal:

Chronic Wound Care Management and Research

\author{
Thomas E Serena' \\ Igal Kushnir ${ }^{2}$ \\ Alon Kushnir ${ }^{2}$ \\ Raphael A Yaakov' \\ Kristen A Eckert ${ }^{3}$ \\ 'Clinical Research, Serena Group, Inc, \\ Cambridge, MA, USA; ${ }^{2}$ RedDress Ltd., \\ Pardes-Hanna, Israel; ${ }^{3}$ Strategic Solutions, \\ Inc, Cody, WY, USA
}

Correspondence: Thomas E Serena Serena Group Inc., 125 Cambridge Park Dr. Suite 30I, Cambridge, MA, USA

Tel + I 6179455225

Fax + I $617299835 \mid$

Email serena@serenagroups.com
Introduction: Blood has become a major source for wound care products due to its primary role in wound healing. The blood clot provides a fibrin scaffold that serves as a protective, provisional extracellular matrix. The clot dries out and becomes a protective scab, under which a moist wound environment can be maintained. In this study, the safety of an autologous whole blood clot product was evaluated in porcine models.

Methods: A total of 24 full thickness dermal wounds were analyzed (6 wounds on each of the 4 porcine models). Eighteen wounds received the whole blood clot product and 6 were treated with saline soaked gauze for 18 days. Reapplications occurred on days 6 and 12 . Histological evaluations were carried out to detect the presence of kaolin. Percentage area reduction and adverse events related to the whole blood clot product were assessed.

Results: Microscopic evaluation revealed that the whole blood clot product was associated with partial to complete wound reepithelialization, whereas minimal reepithelialization was present with the control. The mean reepithelialization score for the control wounds was 1.0, or 2.3 times less than the mean score for the intervention group. By day 18, the mean reduction in wound area was $41 \%$ (SD: 3.8 ) for the control wounds versus $66 \%$ (SD: 6.4 ) for the wounds treated with the whole blood clot product $(P<0.0001)$.

Keywords: blood clot, therapeutics, safety, swine, wounds

\section{Introduction}

Blood-derived products, such as platelets-rich fibrin, platelets-rich plasma, fibrin glue, macrophage, and various growth factors, have gained widespread use. The blood clot provides a fibrin scaffold that serves as a protective, provisional extracellular matrix (ECM). It harbors cytokines and growth factors released by the degranulation of activated platelets. ${ }^{1-4}$ The clot dries out and becomes a protective scab, under which a moist wound environment can be maintained, and tissue remodeling takes place.,

Researchers have developed an autologous whole blood clot product that is created at bedside. Unlike blood-based products, the whole blood clot does not undergo manipulation, separation, or augmentation, however, it is similar to a natural whole blood clot. Blood is mixed with kaolin to accelerate the clot formation. RD1 (RedDress Ltd., Pardes-Hanna, Israel) is a provisional whole blood product that provides a functional ECM, which protects the wound and facilitates the healing process. A recent pilot study demonstrated that the product was safe and efficacious in 7 patients with 9 chronic wounds. ${ }^{6}$ 
Preclinical safety testing of the whole blood clot kit was conducted in response to US Food and Drug Administration (FDA) concerns following reports that kaolin may be toxic to endothelial cells in vitro, have proinflammatory and fibrogenic properties when administered via subcutaneous injection or via intraperitoneal routes, and in topical or granular form may enter bloodstream and result in complications. ${ }^{7-12}$ This study evaluated the safety of the continuous application of the whole blood clot product containing specific kaolin particles on full-thickness dermal wounds in a porcine model for up to 18 days. The secondary objective was to measure the wound healing response, based on reepithelialization and the percentage area reduction (PAR).

\section{Methods and materials}

This study was conducted at NAMSA Laboratories (Northwood, OH, USA) from May 30, 2013 through August 19, 2013 and sponsored by RedDress Ltd. The NAMSA Northwood Division Institutional Animal Care and Use Committee (IACUC) approved the study protocol, which was conducted in accordance with the FDA Good Laboratory Practice Regulations, 21 CFR 58. Animal management and care conformed to NAMSA Standard Operating Procedures, which are based on the Guide for the Care and Use of Laboratory Animals. ${ }^{13}$

Prior to the study, the ability to detect the presence or absence of kaolin particles in tissue, by microscopic analysis, was validated. The validation included transplant of kaolin particles in a rabbit muscle for 2 weeks and thereafter validating the microscopic identification of the particles in the tissue.

The study sample included 4 healthy, previously unused, nonpregnant, and nulliparous female Yucatan Miniature swine (Sus scrofa domesticus) aged 7-8 months, weighing $35-40 \mathrm{~kg}$. Six full thickness dermal wounds were created on the back of each pig (24 total wounds). Three pigs were allocated to the whole blood clot product intervention group (Nos. 5188, 5276, and 5266; $n=18$ wounds); 1 was the control (No. 5265; $n=6$ wounds).

\section{Study materials}

The sponsor provided the whole blood clot product kit, which included a CPDA-1 blood bag (Terumo Corporation, Somerset, NJ, USA), $10 \mathrm{~mL}$ of calcium gluconate 10\% (APP Pharmaceuticals, LLP, Schaumburg, IL, USA), $35 \mathrm{mg}$ sterile kaolin power (Charles B. Crystal Co., Inc., Mamaroneck, NY, USA), and a sterile, plastic clotting tray. The sponsor also provided $2.5 \mathrm{~mL}, 10 \mathrm{~mL}$, and $20 \mathrm{~mL}$ syringes for the whole blood clot product preparation and 3363 nonwoven sponge gauze. NAMSA provided gauze moistened with saline to serve as the control. For both study groups, NAMSA provided Telfa $^{\text {TM }}$ Nonadherent Pad Prepack (Cardinal Health, Marlborough, MA, USA) as primary backing, gauze as secondary backing, and Tegaderm ${ }^{\mathrm{TM}}(3 \mathrm{M}$, St. Paul, MN, USA) to hold the backings in place.

\section{Pretreatment procedures}

A day before wounds were created, each pig was weighed, and food was withheld overnight. After general anesthesia was administered by injection, an endotracheal tube was emplaced, and the pig was attached to an anesthesia machine. The pig was maintained on isoflurane inhalant anesthetic, a ventilator, and a heat source during blood collection and wound procedure. An intravenous catheter was placed in a peripheral vein of the ear for vascular access and fluid administration, as needed. The hair on the dorsal-lateral back area was clipped with an electric clipper and depilated with Veet ${ }^{\circledR}$ (Reckitt Venckiser Group, Slough, UK), a commercial hair remover. The clipped area was scrubbed with nonantiseptic soap, wiped with alcohol 3 times, and left to dry.

To collect blood, the dorsal and ventral neck areas were first shaved, scrubbed with povidone soap and $70 \%$ isopropyl alcohol, sprayed with povidone solution, and draped. An incision was made near the dorsal midline of the neck and on the left side of the neck over the jugular vein. A tunneling trocar was inserted into the dorsal incision to the jugular cut-down incision site. The trocar was removed, and a catheter placed in the jugular vein, using a standard catheter over guidewire insertion procedure. A triple antibiotic ointment was applied to the site to prevent infection. The catheter lumen was flushed and locked with $100 \mathrm{U} / \mathrm{mL}$ heparinized saline or a similar solution.

Approximately $2-3 \mathrm{~mL}$ of blood was collected and disposed of to ensure that all heparinized saline had been removed. Approximately, $8 \mathrm{~mL}$ of blood was collected for the coagulation profile, clinical chemistry analysis, and complete blood cell count. Plasma samples were stored frozen and shipped on dry ice; blood samples were refrigerated and shipped on ice. All blood samples were shipped via next day delivery to Antech Diagnostics GLP (Morrisville, NC, USA), where the hematology and clinical chemistry tests were conducted. 


\section{Wound procedure}

Wounds were created under general anesthesia on day 0 . A scalpel was used to make circular, full-thickness wounds, approximately $4 \mathrm{~cm}$ in diameter and $8-10 \mathrm{~mm}$ deep, on 3 sites of the left and right side of each back. The wound sites were spaced apart, with $1 \mathrm{~cm}$ of skin surrounding each wound. A sterile, nontoxic surgical marker and a template marked wound size and placement. Sterile gauze and digital pressure achieved hemostasis. Cautery prevented any bleeding into the wound. A veterinarian measured the diameter of each wound in 2 directions: cranial-caudal $(\mathrm{CC})$ diameter and dorsal-ventral diameter (DV). The mean wound diameter $(\mathrm{mm})$ was calculated as: $(\mathrm{CC}+\mathrm{DV}) / 2$. Each wound was digitally photographed with a ruler.

\section{Preparation and application of the whole blood clot product}

The calcium gluconate + kaolin suspension was created by mixing $6 \mathrm{~mL}$ of calcium gluconate with kaolin powder. The mixture was shaken to create a uniform suspension. A $20 \mathrm{~mL}$ blood collection syringe (containing CPDA-1) was used to collect approximately $10 \mathrm{~mL}$ of blood from the catheter in the jugular vein. CPDA-1 was mixed with blood immediately after the blood was drawn, without affecting the clotting process. Approximately $2 \mathrm{~mL}$ of the calcium gluconate + kaolin suspension was injected into the blood collection syringe. Air was drawn from the blood collection syringe, which was tilted 3-4 times to mix the contents. The needle was removed from the syringe, and approximately $12 \mathrm{~mL}$ of the blood was injected into the upper hole of the clotting tray using moderate pressure. After 10 mins in the blood clotting tray, the suspension coagulated completely and formed a blood clot. Once the wound bed was relatively dry, the whole blood clot product was placed over the wound with the embedded pad facing upward and shaped, as necessary, by cutting it with sterile scissors. The clot was made large enough to cover the entire $4 \mathrm{~cm}$-diameter wound and at least $0.5 \mathrm{~cm}$ of surrounding skin around the wound edges. The clot was primarily backed with nonwoven sponge gauze and secondarily backed with gauze; all were held in place by Tegaderm ${ }^{\mathrm{TM}}$. The trunk was covered with roll bandages and stockinette to further secure the clot. The product was applied 6 times per pig in the intervention group, or 1 application per wound.

For the control pig, $60 \mathrm{~mL}$ of blood was collected and discarded. For each wound, gauze soaked with approximately
$5 \mathrm{~mL}$ of saline was backed primarily with a nonadherent pad prepack and secondarily with gauze. Tegaderm ${ }^{\mathrm{TM}}$ held the saline-soaked gauze and backing in place. The trunk was covered with roll bandages and stockinette to secure the dressings.

\section{Postoperative procedures}

Feeding was resumed after anesthesia recovery, and a second dose of $0.05 \mathrm{mg} / \mathrm{kg}$ of buprenorphine was administered. Their general health was observed daily. The dressings were observed daily and adjusted, as necessary. Body weights were recorded within $24 \mathrm{hrs}$ of wounding, on day 6, on day 12 (Nos. 5276 and 5266 were weighed on day 13), and at termination. Approximately $24 \mathrm{hrs}$ after treatment application, a veterinarian determined if an anesthetic was needed; the anesthesia procedures, monitoring, and feeding schedules were followed, as previously described.

For each pig, a catheter collected approximately $4-8 \mathrm{~mL}$ of blood on day 1, as per the blood collection procedure previously described. Blood samples were also collected for hematology and clotting profiles prior to each treatment application on days 6 and 12, approximately $24 \mathrm{hrs}$ posttreatment on days 7 and 13, and at termination. Blood was also collected for clinical chemistry analysis at termination.

\section{Reapplication procedure}

Treatment was reapplied on days 6 and 12 for both groups. On days 5 and 11, food was withheld overnight. Prior to reapplication, the wounds were debrided gently with sterile saline. Each wound was gently dried with a gauze pad and then assessed and photographed with a ruler by a veterinarian. Wound assessment involved measuring of the wound diameter and checking for the presence of erythema, edema, exudate, slough/necrotic tissue, granulation tissue, reepithelialization, and the condition of the skin surrounding the wound edge. Each wound characteristic was graded on a scale of 0 through 4 , with 0 representing "not present" and 4 representing "marked".

\section{Termination}

Food was removed at the end of day 17. General anesthesia was induced on day 18. The wound dressings were removed for wound assessment. A catheter collected approximately 4-8 $\mathrm{mL}$ of blood. The pigs were then euthanized.

Each wound was excised, along with approximately $1 \mathrm{~cm}$ of skin surrounding its margin (Figure 1), and labeled with the pig number and wound location, fixed flat in $100 \%$ neutral buffered formalin, and trimmed for histological analysis. Wound sections were embedded in paraffin, sectioned, 


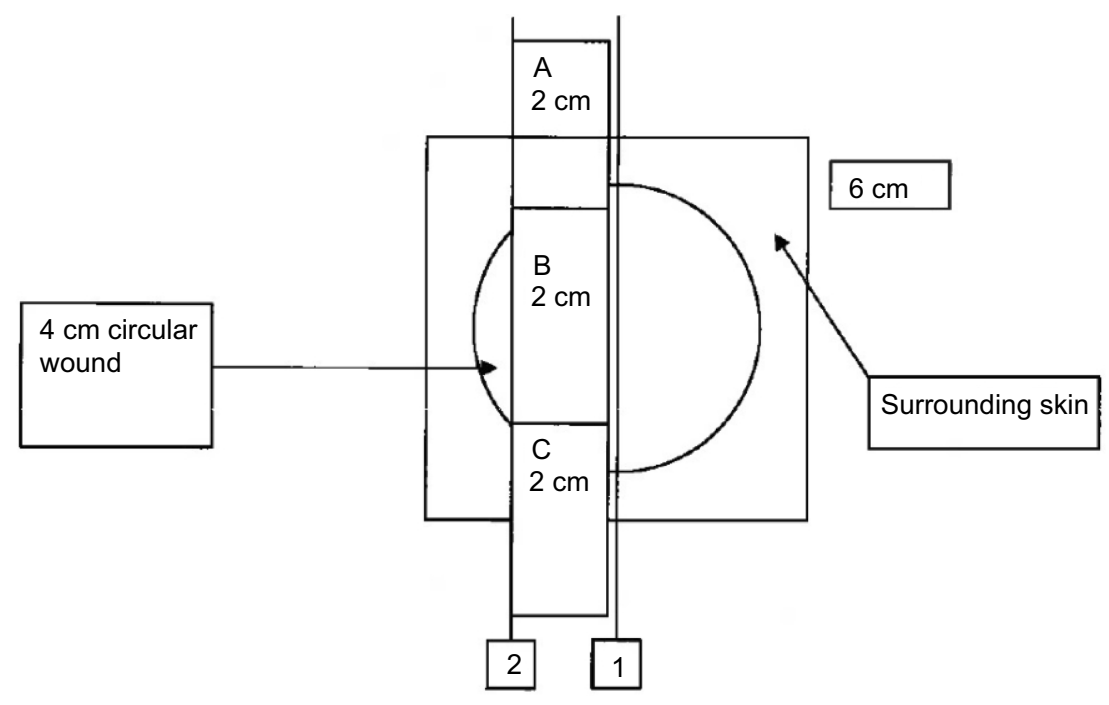

Figure I Schematic diagram of wound excision.

and stained in hematoxylin and eosin for histological evaluation. A blinded pathologist conducted microscopic evaluation of the specimens to detect presence of kaolin particles and measure the healing response, based on local reaction healing characteristics, including the presence of reepithelialization (Table 1). NAMSA technical personnel blinded the slides containing the specimens until the pathologist completed the microscopic evaluation. The pathologist was then unblinded to take images of the microscopic findings and complete a pathology report.

\section{Statistical analysis and additional assessment}

The values for the hematology, coagulation profile, and clinical chemistry tests were evaluated. A mean and SD were calculated for the intervention group. The mean reduction in wound area was calculated using the formula: PAR $=[$ diameter $($ day 0$)-$ diameter $($ each interval $) * 100)] /$ diameter (day 0 ). The PAR between groups was analyzed using a $t$ test with full Bonferroni correction.

\section{Results}

All 4 pigs tolerated the wound procedure, although No. 5265 experienced bradycardia during recovery and was successfully treated with $0.09 \mathrm{~mL}$ of atropine (Fresenius Kabi, Lake Zurich, Illinois) intravenously. Two pigs had no heat source during anesthesia during the wound procedure, and none was on a heat source during the blood collection at termination. No signs of distress were observed, and outcomes were not affected. No kaolin particles were detected in any of the microscopic evaluation.

The 24 wounds ranged in diameter from 36.5 to $41.0 \mathrm{~mm}$ (Table 2). Each wound was approximately 8-10 $\mathrm{mm}$ deep. The mean diameter of the control wounds was $38.1 \mathrm{~mm}$, while the intervention group had a mean wound diameter of $38.9 \mathrm{~mm}$. All pigs maintained a healthy body weight during the study, with some weight loss observed following wound procedure during the first week of the study (Table 3). All pigs tolerated the reapplication procedures.

Clinical observations are summarized in Table 3 . In the intervention group, No. 5188 had bilateral ocular discharge beginning on day 7. Topical ophthalmic medications were provided. Dried blood and eschar were also found along the right side of the jaw. These adverse findings did not appear to be related to the whole blood clot product, and all other pigs appeared normal. No other adverse events occurred.

After 18 days of treatment, there were no clinical pathological changes that were considered related to either intervention or control. All values were within a normal range in both groups, with the exception of an elevated white blood cell (WBC) count after the wound procedure. Before treatment, the $\mathrm{WBC}$ count for the control $\left(5.85 \times 10^{3} / \mathrm{mL}\right)$ was slightly lower than the mean WBC count for the intervention group $\left(8.66 \times 10^{3} / \mathrm{mL}\right.$; SD: 0.24 ; range $8.44-8.91 \times 10^{3} / \mathrm{mL}$ ) (Table 5 ). On day 1 , the WBC count increased to $14.55 \times 10^{3} / \mathrm{mL}$ for the control, and a mean of $16.88 \times 10^{3} / \mathrm{mL}$ (SD: 1.99 ; range: $14.50-17.98$ ) was reported for the intervention group. The WBC count 
Table I Wound histopathology grading scale

\begin{tabular}{|c|c|c|}
\hline Finding(s) & Score & Description \\
\hline Depressed surface & $\begin{array}{l}0 \\
1 \\
2 \\
3 \\
4\end{array}$ & $\begin{array}{l}\text { None } \\
\text { Minimal } \\
\text { Mild } \\
\text { Moderate } \\
\text { Marked }\end{array}$ \\
\hline Sero-cellular crusts & $\begin{array}{l}\text { NP } \\
P\end{array}$ & $\begin{array}{l}\text { Not present (NP) } \\
\text { Exudate on surface of wound or on surface of epithelium (P) }\end{array}$ \\
\hline Epidermal hyperplasia & $\begin{array}{l}0 \\
1 \\
2 \\
3 \\
4\end{array}$ & $\begin{array}{l}\text { None } \\
\text { Minimal } \\
\text { Mild } \\
\text { Moderate } \\
\text { Marked }\end{array}$ \\
\hline Reepithelialization & $\begin{array}{l}0 \\
1 \\
2 \\
3 \\
4\end{array}$ & $\begin{array}{l}\text { None } \\
\text { Minimal: } \leq 1 / 3 \text { of wound surface covered by epithelium } \\
\text { Partial: }>1 / 3 \text { but } \leq 2 / 3 \text { of wound surface covered by epithelium } \\
\text { Extensive: }>2 / 3 \text { of wound surface mostly covered by epithelium } \\
\text { Complete: all wound surface covered by epithelium }\end{array}$ \\
\hline Granulation tissue & $\begin{array}{l}0 \\
1 \\
2 \\
3 \\
4\end{array}$ & $\begin{array}{l}\text { Wound unhealed, devoid of granulation tissue } \\
\text { Wound filled with only immature tissue } \\
\text { Wound filled by immature and mature collagen } \\
\text { Wound mostly filled by mature collagen with some immature tissue } \\
\text { Wound completely filled by mature collagen }\end{array}$ \\
\hline Necrotic tissue & $\begin{array}{l}0 \\
1 \\
2 \\
3 \\
4\end{array}$ & $\begin{array}{l}\text { None } \\
\text { Minimal } \\
\text { Mild } \\
\text { Moderate } \\
\text { Marked }\end{array}$ \\
\hline \multicolumn{3}{|c|}{ Inflammatory cell response } \\
\hline Foreign debris $^{\mathrm{a}}$ & $\begin{array}{l}0 \\
1 \\
2 \\
3 \\
4\end{array}$ & $\begin{array}{l}\text { None } \\
\text { Minimal } \\
\text { Mild } \\
\text { Moderate } \\
\text { Marked }\end{array}$ \\
\hline Hemorrhage & $\begin{array}{l}0 \\
1 \\
2 \\
3 \\
4\end{array}$ & $\begin{array}{l}\text { None } \\
\text { Minimal } \\
\text { Mild } \\
\text { Moderate } \\
\text { Marked }\end{array}$ \\
\hline
\end{tabular}

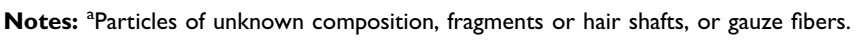

fluctuated but remained consistently higher than the baseline value for the study duration. All pigs appeared macroscopically normal at termination. There was no difference in organ weights between the 2 groups that were considered to be product related.
Microscopic evaluation revealed that the whole blood clot product was associated with partial-to-complete wound reepithelialization (Figure 2), whereas minimal reepithelialization was present with the control (Figure 3). Granulation tissue formation and inflammatory cell responses were similar in 
Table 2 Mean wound diameter and percent of wound healed per animal

\begin{tabular}{|c|c|c|c|c|c|c|c|c|c|}
\hline \multirow[t]{2}{*}{ Number/group } & \multirow[t]{2}{*}{ Side } & \multirow[t]{2}{*}{ Wound site } & \multicolumn{4}{|c|}{ Wound diameter (mm) } & \multicolumn{3}{|c|}{ Wound area reduction (\%) } \\
\hline & & & Day 0 & Day 6 & Day 12 & Day 18 & Day 6 & Day 12 & Day 18 \\
\hline \multirow[t]{6}{*}{$5265 /$ Control } & \multirow[t]{3}{*}{ Left } & Cranial & 38.5 & 40.0 & 32.5 & 22.5 & -4 & 16 & 42 \\
\hline & & Medial & 38.0 & 38.5 & 34.5 & 25.0 & -1 & 9 & 34 \\
\hline & & Caudal & 39.5 & 39.0 & 31.0 & 22.5 & 1 & 22 & 43 \\
\hline & \multirow[t]{3}{*}{ Right } & Cranial & 35.0 & 35.5 & 33.0 & 19.5 & -1 & 6 & 44 \\
\hline & & Medial & 37.5 & 38.0 & 32.0 & 22.5 & -1 & 15 & 40 \\
\hline & & Caudal & 40.0 & 38.5 & 31.5 & 22.5 & 4 & 21 & 44 \\
\hline \multirow[t]{6}{*}{$5188 /$ Intervention } & \multirow[t]{3}{*}{ Left } & Cranial & 37.5 & 39.5 & 34.0 & 14.0 & -5 & 9 & 63 \\
\hline & & Medial & 36.5 & 36.5 & 31.5 & 14.5 & 0 & 14 & 60 \\
\hline & & Caudal & 37.5 & 36.5 & 28.5 & 8.0 & 3 & 24 & 79 \\
\hline & \multirow[t]{3}{*}{ Right } & Cranial & 38.5 & 39.0 & 27.0 & 9.5 & -1 & 30 & 75 \\
\hline & & Medial & 38.0 & 39.0 & 28.5 & 15.5 & -3 & 25 & 59 \\
\hline & & Caudal & 39.0 & 39.0 & 28.5 & 14.0 & 0 & 27 & 64 \\
\hline \multirow[t]{6}{*}{$5276 /$ Intervention } & \multirow[t]{3}{*}{ Left } & Cranial & 41.0 & 42.5 & 31.0 & 11.0 & -4 & 24 & 73 \\
\hline & & Medial & 39.0 & 40.5 & 28.5 & 14.0 & -4 & 27 & 64 \\
\hline & & Caudal & 38.5 & 40.0 & 26.0 & 15.0 & -4 & 33 & 61 \\
\hline & \multirow[t]{3}{*}{ Right } & Cranial & 40.0 & 39.0 & 25.0 & 10.5 & 3 & 38 & 74 \\
\hline & & Medial & 39.0 & 38.5 & 24.0 & 12.0 & I & 39 & 69 \\
\hline & & Caudal & 40.0 & 38.5 & 23.0 & 12.5 & 4 & 43 & 69 \\
\hline \multirow[t]{6}{*}{$5266 /$ Intervention } & \multirow[t]{3}{*}{ Left } & Cranial & 40.0 & 39.5 & 29.5 & 16.0 & I & 26 & 60 \\
\hline & & Medial & 38.0 & 37.5 & 26.5 & 17.0 & I & 30 & 55 \\
\hline & & Caudal & 39.5 & 39.0 & 25.0 & 15.5 & I & 37 & 61 \\
\hline & \multirow[t]{3}{*}{ Right } & Cranial & 39.5 & 38.0 & 23.5 & 13.5 & 4 & 41 & 66 \\
\hline & & Medial & 38.0 & 36.0 & 26.0 & 11.5 & 5 & 32 & 70 \\
\hline & & Caudal & 40.0 & 38.0 & 24.5 & 12.5 & 5 & 39 & 69 \\
\hline
\end{tabular}

both groups. Birefringent particulate foreign debris was present in the granulation tissue of the wound beds of both groups, and the kaolin particles of the product could not be differentiated.

On day 6 , the mean wound diameter was similar for both groups (control: $38.3 \mathrm{~mm}$; intervention: $38.7 \mathrm{~mm}$ ). Wound characteristics are scored in Table 4. The mean score for reepithelialization was 0 for both groups on day 6 . By day 18 , the mean reepithelialization score for the control wounds was 1.0 , or 2.3 times less than the mean score for the intervention group of 2.3 .

Decreasing wound diameters suggested that healing was occurring for both groups, with more healing observed in the intervention group over time (Table 2). By day 18, the mean reduction in wound area was $41 \%$ (SD: 3.8 ) for the control wounds versus $66 \%$ (SD: 6.4 ) for the wounds treated with the whole blood clot product $(P<0.0001)$.

\section{Discussion}

The study showed zero migration of kaolin particles from the clot to the tissue. A statistically significant reduction in wound area was observed over time in the intervention group $(66 \%)$ on day 18 compared to the control (41\%). Thus, the whole blood clot product appears to be a beneficial treatment for acute full-thickness wounds. No adverse events occurred that were product-related. The fluctuating, elevated WBC counts observed in both groups after the wounding procedure were considered a normal inflammatory response associated with the wounding and healing process.

This is the first study to evaluate the safety of an autologous whole blood clot product that uses kaolin to accelerate the coagulation process with regards to kaolin migration from the clot to the wound tissue. Previous safety concerns over the use of kaolin are from the kaolin-coated combat gauze (CG) used in cases of severe hemorrhaging, not non-bleeding wounds. In addition, while CG was reported to be cytotoxic to endothelial cells, only the cell viability of human umbilical vein endothelial cells was affected when $0.1 \mathrm{mg} / \mathrm{mL}$ of kaolin was introduced in a cell culture assay that also included HeLa cells and RAW267.4 murine cells. ${ }^{7}$ Furthermore, CG uses approximately $1.5 \mathrm{~g}$ of kaolin, which is 50 times the amount used in the whole blood clot product. CG has been deemed 


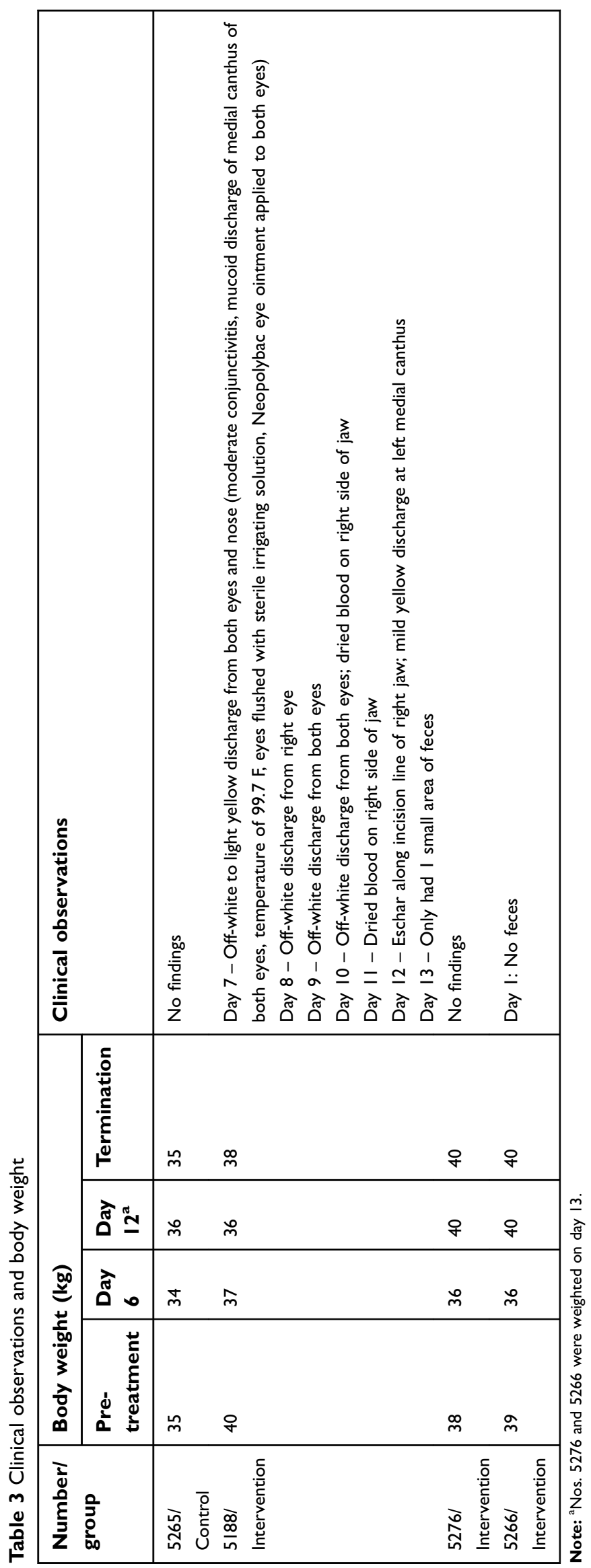




\section{Test - 5266 right cranial wound}

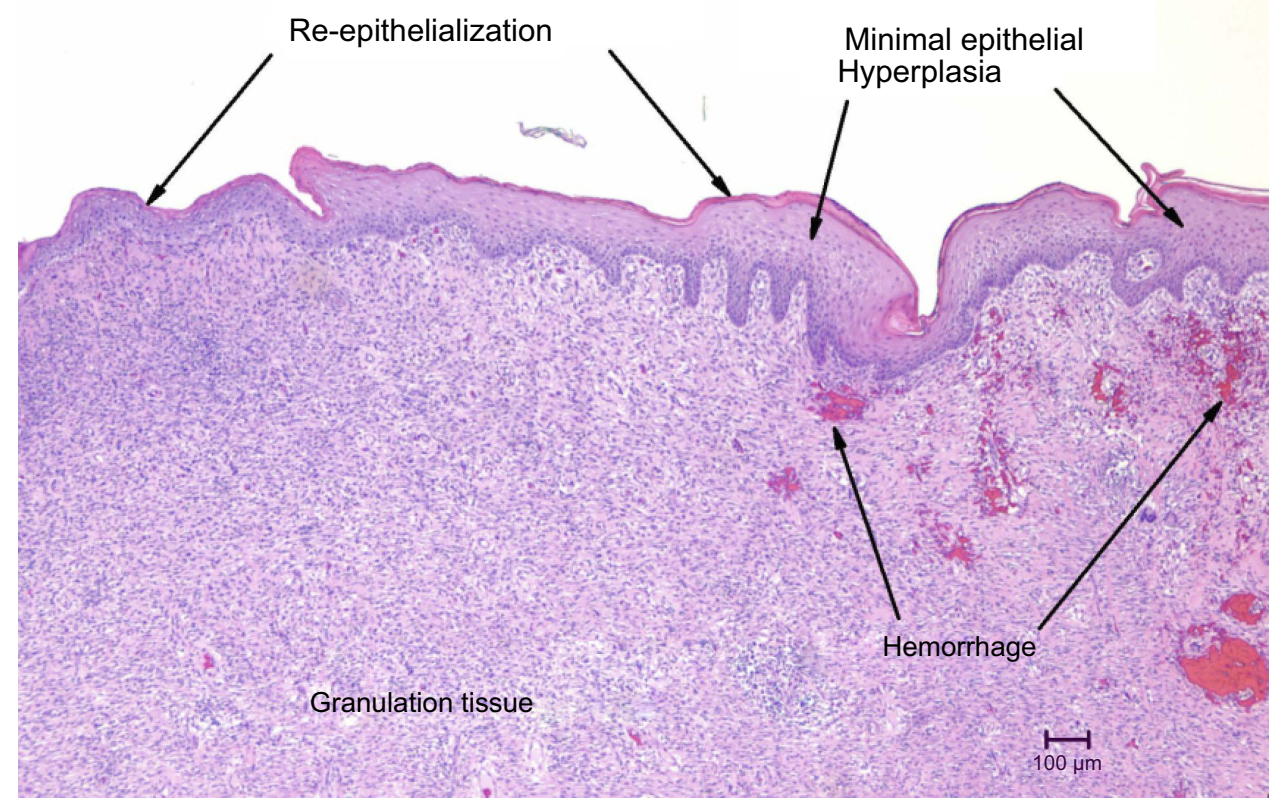

Figure 2 Test 5266 right cranial wound.

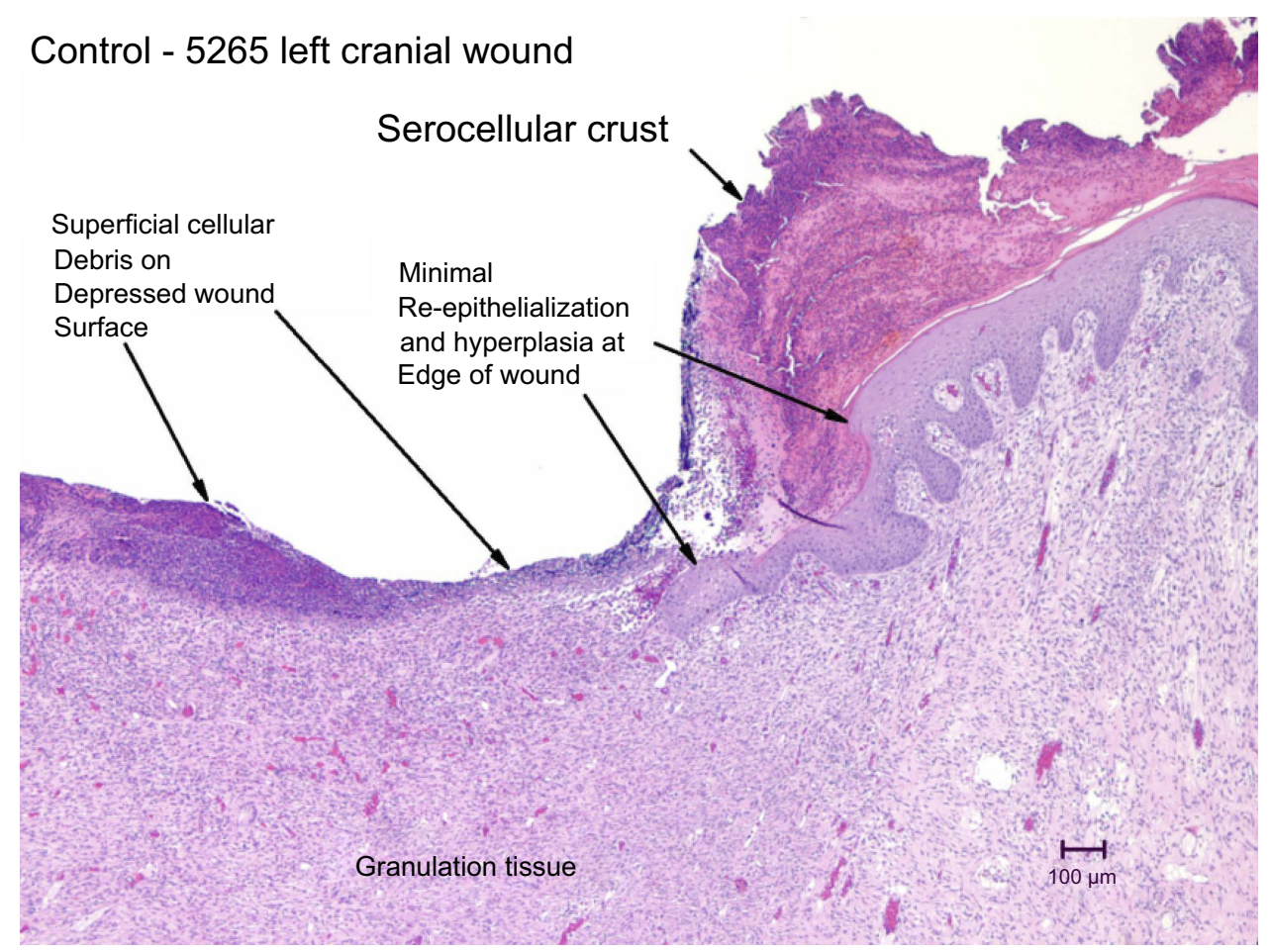

Figure 3 Control 5265 left cranial wound. 
Table 4 Summary of wound scoring per study group

\begin{tabular}{|c|c|c|}
\hline \multirow[t]{2}{*}{ Wound observation } & \multicolumn{2}{|c|}{ Mean score ${ }^{a}$ of wounds } \\
\hline & $\begin{array}{l}\text { Control, } \\
n=6\end{array}$ & $\begin{array}{l}\text { Intervention, } \\
n=18\end{array}$ \\
\hline \multicolumn{3}{|l|}{ Erythema } \\
\hline Day 6 & 3.0 & 2.4 \\
\hline Day 12 & 1.5 & 1.8 \\
\hline Day 18 & 1.0 & 0.9 \\
\hline \multicolumn{3}{|l|}{ Edema } \\
\hline Day 6 & 1.2 & 1.3 \\
\hline Day 12 & 0.8 & 0.7 \\
\hline Day 18 & 0.0 & 0.0 \\
\hline \multicolumn{3}{|l|}{$\begin{array}{l}\text { Presence of slough/necrotic } \\
\text { tissue }\end{array}$} \\
\hline Day 6 & 0.0 & 2.8 \\
\hline Day 12 & 0.7 & 1.0 \\
\hline Day 18 & 1.8 & 1.4 \\
\hline \multicolumn{3}{|l|}{ Presence of granulation tissue } \\
\hline Day 6 & 1.3 & 2.6 \\
\hline Day 12 & 2.0 & 3.6 \\
\hline Day 18 & 3.7 & 4.0 \\
\hline \multicolumn{3}{|l|}{ Reepithelialization } \\
\hline Day 6 & 0.0 & 0.0 \\
\hline Day 12 & 0.5 & 1.3 \\
\hline Day 18 & 1.0 & 2.3 \\
\hline \multicolumn{3}{|l|}{$\begin{array}{l}\text { Edema of skin surrounding the } \\
\text { wound }\end{array}$} \\
\hline Day 6 & 0.0 & 0.0 \\
\hline Day 12 & 0.0 & 0.0 \\
\hline Day 18 & 0.0 & 0.0 \\
\hline \multicolumn{3}{|l|}{$\begin{array}{l}\text { Erythema of skin surrounding } \\
\text { the wound }\end{array}$} \\
\hline Day 6 & 0.0 & 0.0 \\
\hline Day 12 & 0.0 & 0.0 \\
\hline Day 18 & 0.0 & 0.0 \\
\hline
\end{tabular}

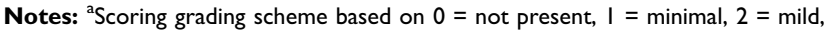
$3=$ moderate, $4=$ marked.

safe and is the primary treatment for combat wounds with severe bleeding ${ }^{14-16}$
Literature has suggested that kaolin particles of the whole blood clot product might remain in the wound bed and cause complications. ${ }^{12}$ However, in our study, kaolin was not detected microscopically in the birefringent particulate foreign debris that is normally found in wound granulation tissue. Moreover, there was more foreign debris in the control wound beds than in the beds of wounds treated with the product. Kaolin provided in the form of powder binds to the blood in vitro prior to application to the wound, whereas CG involves a granular form of kaolin. Although it has been suggested that granular kaolin particles can enter systemic circulation, there were no differences in vascular function between the CG-treated and control combat trauma wounds in that study. ${ }^{12}$

Kaolin has been used to promote an inflammatory response in animal models, but inflammation is a natural step of the wound healing process. ${ }^{8,9}$ Also, the current study used up to 17 times less the amount of kaolin used in other animal studies.

Kaolin was thought to be associated with granuloma in a case study of 2 patients, who had kaolin poultices applied to a ruptured inflammatory mass and sinus above the left breast. ${ }^{10}$ This was the first and only published report of such an occurrence following the use of kaolin poultices, and it cannot be determined from the study design if kaolin was the cause. The World Health Organization (WHO) reported that the application of kaolin demonstrated fibrogenic properties when administered to animals via the intratracheal and parental routes; however, these routes do not apply to the whole blood clot product. ${ }^{11}$ Furthermore, the WHO also recognized that kaolin is commonly used in cosmetics and has shown no adverse events to indicate it may be unsafe when administered via the dermal route. Our safety findings for the whole blood clot product suggest that kaolin would not be harmful to the wound and that its use with the product is safe.

The current study only evaluated the safety of the product for up to 18 days. Another limitation was the small sample size and use of one animal in the control group. The findings from the porcine model are also limited in their

Table 5 Summary of white blood cell count $\left(10^{3} / \mu \mathrm{L}\right)$ per study group

\begin{tabular}{|l|l|l|l|l|l|l|l|}
\hline Group & Pretreatment & Day I & Day 6 & Day 7 & Day I2 & Day I3 & Termination \\
\hline $\begin{array}{l}\text { Control, } n=1 \\
\text { Intervention, } n=3\end{array}$ & 5.85 & 14.6 & 13.3 & 11.0 & 6.2 & 14.8 & 10.4 \\
Mean & & & & & & & \\
SD & 8.7 & 16.8 & 17.0 & 13.8 & 10.9 & 16.6 & 13.9 \\
Range & 0.24 & 1.99 & 3.58 & 4.18 & 2.54 & 3.09 & 1.58 \\
\end{tabular}


relevance to human wounds, as there is no animal model that fully mimics human wounds. ${ }^{17}$ However, a small pilot study was recently published that evaluated the safety and efficacy of the whole blood clot product in 7 patients with 9 chronic wounds of various etiologies. ${ }^{6}$

\section{Conclusions}

The findings of this study suggest that the whole blood clot product is safe in acute, full-thickness dermal wounds in a porcine model. There were no adverse findings related to the product, and the kaolin particles of the product could not be differentiated microscopically. An improved healing response was also observed compared to the control, which has been further supported by a recent pilot study on human patients. The long-term safety of the product on patients with diabetic foot ulcers is under investigation.

\section{Acknowledgment}

The authors would like to thank Dr Marissa Carter, President, Strategic Solutions, Inc (Cody, WY, USA), for her valuable input and technical support during the analysis and preparation of this manuscript.

\section{Disclosure}

This study was sponsored by RedDress Ltd. Alon Kushnir and Igal Kushnir are employees of RedDress Ltd. Thomas E Serena reports grants from RedDress Ltd. during the conduct of the study and is affiliated with Serena Group, Inc. Igal Kushnir reports fees from RedDress Ltd. during the conduct of the study, nothing from RedDress Ltd. outside the submitted work, and has a patent issued: 9,180,142. Alon Kushnir reports fees from RedDress Ltd. during the conduct of the study and outside the submitted work, and has a patent issued: 9,180,142. Raphael A Yaakov is affiliated with Serena Group, Inc. Kristen A Eckert was affiliated with and reports personal fees from Strategic Solutions, Inc, during the conduct of the study. The authors report no other conflicts of interest in regard to this work.

\section{References}

1. Miron RJ, Fujioka-Kobayashi M, Bishara M, Zhang Y, Hernandez M, Choukroun J. Platelet-rich fibrin and soft tissue wound healing: a systematic review. Tissue Eng Part B Rev. 2017;23:83-99. doi:10.1089/ten.teb.2016.0233
2. Singer AJ, Clark RA. Cutaneous wound healing. $N$ Engl $J$ Med. 1999;341:738-746. doi:10.1056/NEJM199909023411006

3. Laurens N, Koolwijk P, de Maat MP. Fibrin structure and wound healing. J Thromb Haemost. 2006;4:932-939. doi:10.1111/j.15387836.2006.02117.x

4. Tonnesen MG, Feng X, Clark RA. Angiogenesis in wound healing. J Investig Dermatol Symp Proc. 2000;5:40-46. doi:10.1046/j.10870024.2000.00014.x

5. Clark RAF, ed. The Molecular and Cellular Biology of Wound Repair. 2nd ed. Norwell, MA: Kluwer Academic Publishers; 1996.

6. Kushnir I, Kushnir A, Serena TE, Garfinkel D. Efficacy and safety of a novel autologous wound matrix in the management of complicated, chronic wounds: a pilot study. Wounds. 2016;28:317-327.

7. Bowman PD, Wang X, Meledeo MA, Dubick MA, Kheirabadi BS. Toxicity of aluminum silicates used in hemostatic dressings toward human umbilical veins endothelial cells, HeLa cells, and RAW267.4 mouse macrophages. J Trauma. 2011;71:727-732. doi:10.1097/ TA.0b013e3182033579

8. Giraudel JM, Diquelou A, Lees P, Toutain PL. Development and validation of a new model of inflammation in the cat and selection of surrogate endpoints for testing anti-inflammatory drugs. $J$ Vet Pharmacol Ther. 2005;28:275-285. doi:10.1111/jvp. 2005.28.issue-3

9. Fosse TK, Spadavecchia C, Horsberg TE, Haga HA, Ranheim B. Pharmacokinetics and pharmacodynamic effects of meloxicam in piglets subjected to a kaolin inflammation model. $J$ Vet Pharmacol Ther. 2011;34:367-375. doi:10.1111/jvp.2011.34. issue-4

10. Potts RE. Kaolin granuloma. Br $J$ Surg. 1953;41:295-299. doi:10.1002/(ISSN)1365-2168

11. World Health Organization. Environmental Health Criteria 231. Bentonite, Kaolin, and Selected Clay Minerals; 2005. Available from: http://www.who.int/ipcs/publications/ehc/ehc_231.pdf. Accessed June 03, 2015.

12. Kheirabadi BS, Mace JE, Terrazas IB, et al. Safety evaluation of new hemostatic agents, smectite granules, and kaolin-coated gauze in a vascular injury wound model in swine. $J$ Trauma. 2010;68:269-278; Erratum in: J Trauma. 2010; 68: 1263. doi:10.1097/TA.0b013e3181c97ef1

13. Institute for Laboratory Animal Research. National Research Council of the National Academies. Guide for the Care and Use of Laboratory Animals. 8th ed. 2011. Available from: http://grants.nih. gov/grants/olaw/Guide-for-the-Care-and-Use-of-LaboratoryAnimals.pdf Accessed June 08, 2015.

14. Martin MJ. Editorial to accompany A pilot study of the use of kaolin-impregnated gauze (Combat Gauze) for packing high-grade hepatic injuries in a hypothermic coagulopathic swine model. J Surg Res. 2014;186:116-118. doi:10.1016/j. jss.2013.03.010.

15. Kheirabadi BS, Scherer MR, Estep JS, et al. Determination of efficacy of new hemostatic dressings in a model of extremity arterial hemorrhage in swine. J Trauma. 2009;67:450-459; discussion 459-460. doi:10.1097/TA.0b013e3181ac0c99

16. Committee on Tactical Combat Casualty Care. Tactical Combat and Casualty Care Guidelines. 2014. Available from: http://www.itstacti cal.com/medcom/tccc-medcom/2014-tccc-tactical-combat-casualtycare-guidelines/. Accessed October 31, 2016.

17. Salcido R, Popescu A, Ahn C. Animal models in pressure ulcer research. J Spinal Cord Med. 2007;30:107-116. doi:10.1080/ 10790268.2007.11753921 


\section{Publish your work in this journal}

Chronic Wound Care Management and Research is an international, peer reviewed, open access, online journal publishing original research, reviews, editorials, and commentaries on the causes and management of chronic wounds and the major issues related to chronic wound management. Topics also include chronic wounds as comorbidities to other conditions, patient adherence to therapy, and the economic burden of chronic wounds. The manuscript management system is completely online and includes a very quick and fair peer review system, which is all easy to use. Visit http://www.dovepress.com/ testimonials.php to read real quotes from published authors.

Submit your manuscript here: https://www.dovepress.com/chronic-wound-care-management-and-research-journal 